\title{
Comparison of Neuroprotective and Cognition-Enhancing Properties of Hydrolysates from Soybean, Walnut, and Peanut Protein
}

\author{
Wenzhi Li,, ${ }^{1,2}$ Tiantian Zhao, ${ }^{1,2}$ Jianan Zhang, ${ }^{1,2}$ Changping Wu, ${ }^{1,2}$ \\ Mouming Zhao, ${ }^{1,2}$ and Guowan $\mathrm{Su}^{1,2}$ \\ ${ }^{1}$ School of Food Science and Engineering, South China University of Technology, Guangzhou 510640, China \\ ${ }^{2}$ Guangdong Food Green Processing and Nutrition Regulation Technologies Research Center, Guangzhou 510650, China
}

Correspondence should be addressed to Guowan Su; fegwsu@scut.edu.cn

Received 14 April 2016; Revised 18 May 2016; Accepted 20 June 2016

Academic Editor: Filomena Conforti

Copyright ( $) 2016$ Wenzhi Li et al. This is an open access article distributed under the Creative Commons Attribution License, which permits unrestricted use, distribution, and reproduction in any medium, provided the original work is properly cited.

Hydrolysates were prepared from soybean, walnut, and peanut protein by papain, respectively. Their amino acid compositions and molecular weight distributions, the effects of various hydrolysates on $\mathrm{H}_{2} \mathrm{O}_{2}$-induced injury PC12 cells, and cognition of mice were investigated, respectively. Results showed that the three hydrolysates were dominated by the peptides with $1-3 \mathrm{KDa}$ with large amount of neurotrophic amino acids. All the hydrolysates exhibited much stronger inhibitory activity against $\mathrm{H}_{2} \mathrm{O}_{2}-$ induced toxicity than cerebrolysin, and soy protein hydrolysate showed the highest activity. Moreover, the hydrolysates also could reduce the rate of nonviable apoptotic cells at the concentration of $2 \mathrm{mg} / \mathrm{mL}$. The test of animal's cognition indicated that three hydrolysates could present partly better effect of improving recurred memory ability of normal mice and consolidated memory ability of anisodine-treated mice than piracetam. Therefore, soybean, walnut, and peanut protein hydrolysates were recommended as a potential food raw material for prevention or treatment of neurodegenerative disorders.

\section{Introduction}

Alzheimer's disease $(\mathrm{AD})$ is a neurodegenerative disease of the brain. The population suffering from $\mathrm{AD}$ is currently up to 20 million worldwide and is predicted to be between 30 and 40 million worldwide by 2050 [1]. According to many studies, two factors related to $\mathrm{AD}$ progress have received considerable attention, which referred to antioxidative and neuroprotective functions [2]. Therefore, the discovery of new materials with neurotrophic and neuroprotective properties is becoming a new strategy for the treatment of neurodegenerative disorders. Specific daily dietary foods have also been recognized as likely contributors to a greater or lower risk of developing AD. For example, high intake of fish is associated with a lower risk of $\mathrm{AD}$ due to the high level of omega-3 fatty acids [3]. Other foods associated with decreased risk of AD include folic acid-containing foods such as green vegetables, citrus fruits, liver, and whole grains [4].
Walnut has been used in traditional medicine for treatment of various diseases owing to its polyphenols or polyunsaturated fat [5]. Meanwhile, its antioxidative and angiotensin-I-converting-enzyme (ACE) inhibitory functions [6] and other biological functions have also been reported. Additionally, the antioxidant activity and ACE inhibitory activity were also discovered in peanut protein hydrolysate [7]. Recently, peptides have been shown to have neurotrophic and neuroprotective potential as demonstrated both in vivo and in vitro. Liu et al. [8] reported that soybean peptides could protect $\mathrm{PC} 12$ cells against $\mathrm{H}_{2} \mathrm{O}_{2}$-induced lipid peroxidation and cell apoptosis as a neuroprotective agent. It was reported that cerebrolysin is an effective means of treating cerebral vascular insufficiency patients. It could decrease the severity of memory and attention impairments to improve the overall cognitive status of the patients [9]. Thus, peptides derived from food could possess multiple mechanisms of action on alleviating cognitive deficits. 
The objective of this study is to compare the antioxidative and neuroprotective properties of hydrolysates from soybean protein, walnut protein, and peanut protein, respectively. To clarify their different effects on alleviating memory deficits, the antioxidative, PC12 cell protection, and behavioral tests were conducted.

\section{Experimental}

2.1. Materials. Defatted peanut meal was purchased from Shandong Luhua Group Co. Ltd. Defatted soybean meal was purchased from Yuwang Soy Company (Shandong, China). Defatted walnut meal was purchased by Huizhiyuan Food Co. Ltd. (Lincang, China). Papain was obtained from Guangzhou Huaqi Biotechnology Co. (Guangzhou, China). All the other chemicals and solvents were of analytical grade.

2.2. Preparation of Hydrolysates. Fifty grams of protein materials (defatted soybean meal, defatted walnut meal, and defatted peanut meal) was mixed with $100 \mathrm{~mL}$ of deionized water, respectively, and homogenized at 10,000 rpm for $1 \mathrm{~min}$ using an Ultra Turrax homogenizer (Beijing Jingke Huarui Instrument Co. Ltd., Beijing, China). The three homogenates were all preincubated at $55^{\circ} \mathrm{C}$ for $20 \mathrm{~min}$ prior to enzymatic hydrolysis using papain. All the mixtures were conducted at $\mathrm{pH}$ 7.0, respectively. The $\mathrm{pH}$ of the slurries was constantly maintained during hydrolysis by addition of $2 \mathrm{M} \mathrm{NaOH}$. When the degree of hydrolysis reached $10 \%$, the enzyme was inactivated at $95^{\circ} \mathrm{C}$ for $15 \mathrm{~min}$. The hydrolysates were centrifuged in a GL-21M refrigerated centrifuge (Xiangyi Instrument Co. Ltd., Changsha, China) at 5,000 $\times \mathrm{g}$ for $20 \mathrm{~min}$ at $20^{\circ} \mathrm{C}$ and the supernatants were collected, lyophilized (R2L-100KPS, Kyowa Vacuum Engineering, Tokyo, Japan), and stored in a desiccator for further analysis. Hydrolysate from soybean protein will be expressed as $\mathrm{SPH}$, from walnut protein as WPH, and from peanut protein as $\mathrm{PPH}$ for short, respectively.

2.3. Molecular Weight Distribution of Peptides in SPH, WPH, and $P P H$. The molecular weight distribution of peptides in $\mathrm{SPH}, \mathrm{WPH}$, and $\mathrm{PPH}$ was determined by gel filtration chromatography, at a wavelength of $214 \mathrm{~nm}$ using an HPLC system equipped with a TSK gel G2000 SWXL analytical column, respectively. The mobile phase (isocratic elution, $0.02 \mathrm{M}$ sodium phosphate buffer) was at a flow rate of $0.5 \mathrm{~mL} / \mathrm{min}$. Six protein and peptide standards, conalbumin $(75,000 \mathrm{Da})$, ovalbumin $(43,000 \mathrm{Da})$, cytochrome C (12,384 Da), aprotinin $(6,512 \mathrm{Da})$, vitamin $\mathrm{B} 12(1,855 \mathrm{Da})$, and glutathione $(307 \mathrm{Da})$, were used to establish a reference calibration curve. The fitting line equation, that is, the logarithm of the relative MW versus elution volume, was $y=0.1547 x+5.6431\left(R^{2}=\right.$ 0.9957 ), where $y$ is the logarithm of standard peptide MW and $x$ is the elution volume.

2.4. Amino Acid Composition of SPH, WPH, and PPH. Amino acid analysis was performed following the method of Fujiwara et al. [10] using an A300 auto-amino acid analyzer (MembraPure, Bodenheim, Germany) based on ophthalaldehyde derivatives.

2.5. NGF-Differentiated PC12 Cells Culture. PC12 cells were cultured in $25 \mathrm{~cm}^{2}$ flasks in growth medium composed of Dulbecco's modified Eagle's medium (DMEM) supplemented with $5 \%$ fetal calf serum (FCS), 10\% horse serum (HS), $10,000 \mathrm{U} / \mathrm{mL}$ penicillin, and $100 \mu \mathrm{g} / \mathrm{mL}$ streptomycin. Cells were grown at $37^{\circ} \mathrm{C}$, in a humidified atmosphere of $5 \%$ $\mathrm{CO}_{2}$. Actively proliferating PC12 cells $\left(2 \times 10^{5}\right.$ cells/well $)$ were seeded onto 12 -well plates precoated with $200 \mu \mathrm{g} / \mathrm{mL}$ collagen type-I and differentiated with $50 \mathrm{ng} / \mathrm{mL}$ Nerve Growth Factor (NGF) for 2 days. Fresh medium-containing NGF was changed every three days. In all experiments, only NGF-differentiated PC12 cells were used. The morphologic observation and the detection of microtubule-associated protein 2 (MAP2) expression by immunohistochemistry test were conducted to identify the differentiated neurons.

2.6. MTT Cell Proliferation Assay. For assay performance, the NGF-differentiated PC12 cells were harvested from the flasks using a $0.25 \%$ trypsin/EDTA $1 x$-solution (Gibco) and were counted using a CASY cell counter (Roche) and $5 \times$ $10^{3}$ cells per well $(100 \mu \mathrm{L})$ were seeded in coated 96-wellplate. After 72 hours, SPH, WPH, PPH, and cerebrolysin were individually added into the wells with the final concentrations of $5,2,1,0.5,0.2,0.1,0.05$, and $0 \mathrm{mg} / \mathrm{mL}$. The 96 -well plate was again incubated for 24 hours following MTT assay. MTT $(0.5 \mathrm{mg} / \mathrm{mL})$ were added to each well and the plate was incubated for another $4 \mathrm{~h}$ at $37^{\circ} \mathrm{C}$. Then, the supernatant was removed, and $100 \mu \mathrm{L}$ of dimethyl sulfoxide was added to each well. MTT metabolism was measured spectrophotometrically at $490 \mathrm{~nm}$ in a Biorad microplate reader (Biotek Instruments, Burlington, VT, USA). Results were expressed as the percentage of MTT reduction, taking the absorbance of control cells as $100 \%$.

2.7. Flow Cytometry Analysis of Apoptosis. Flow cytometry analysis of apoptosis was done to detect the possible proapoptotic effects of SPH, WPH, and PPH. The NGFdifferentiated PC12 was seeded at a concentration of $5 \times 10^{3}$ cells/well in a 96-well plate and grown in DMEM medium containing 5\% FCS and $10 \% \mathrm{HS}$ for $72 \mathrm{~h}$ at $37^{\circ} \mathrm{C}$. Then, cells were treated with $0.1 \mathrm{mmol} / \mathrm{L}$ of $\mathrm{H}_{2} \mathrm{O}_{2}$ for $30 \mathrm{~min}$ and were individually preincubated with $\mathrm{SPH}(0,1,2$, and $5 \mathrm{mg} / \mathrm{mL})$, $\mathrm{WPH}(0,1,2$, and $5 \mathrm{mg} / \mathrm{mL}), \mathrm{PPH}(0,1,2$, and $5 \mathrm{mg} / \mathrm{mL})$, and cerebrolysin $(0,1,2$, and $5 \mathrm{mg} / \mathrm{mL})$ for $48 \mathrm{~h}$. Cells without treatment of $\mathrm{H}_{2} \mathrm{O}_{2}$ were taken as control. The cell samples were trypsinized and then centrifuged at $1000 \mathrm{rpm}$ for $5 \mathrm{~min}$. The cells were resuspended with $500 \mu \mathrm{L}$ binding buffer at a concentration of $10^{6}$ cells $/ \mathrm{mL}$, after washing two times with PBS at $1000 \mathrm{rpm}$ for $5 \mathrm{~min}$. Then, $5 \mathrm{~mL}$ FITC-conjugated annexin $\mathrm{V}$ and $5 \mathrm{~mL}$ PI were added to the cells and incubated at room temperature for $15 \mathrm{~min}$ in the dark. The samples were analyzed by flow cytometry within $1 \mathrm{~h}$ after staining. Experiments were repeated three times. 
2.8. Animal Experiments. NIH (National Institutes of Health) mice were used to detect the effects of SPH, WPH, and PPH on cognition. Seventy-five health female mice, $20 \pm 2 \mathrm{~g}$ from Guangdong Medical Lab Animal Center, were randomly divided into 9 groups $\left(\mathrm{C}, \mathrm{H}_{1}, \mathrm{H}_{2}, \mathrm{H}_{3}, \mathrm{HA}_{1}, \mathrm{HA}_{2}, \mathrm{HA}_{3}, \mathrm{CA}\right.$, and $\mathrm{P}$ ). Group $\mathrm{C}$ is the control group with oral administration of distilled water; Group $\mathrm{H}_{1}$ with oral administration of SPH; Group $\mathrm{H}_{2}$ with oral administration of WPH; Group $\mathrm{H}_{3}$ with oral administration of $\mathrm{PPH}$; Group $\mathrm{HA}_{1}$ with oral administration of $\mathrm{SPH}$ and anisodine in turn; Group $\mathrm{HA}_{2}$ with oral administration of WPH and anisodine in turn; Group $\mathrm{HA}_{3}$ with oral administration of $\mathrm{PPH}$ and anisodine in turn; Group CA with oral administration of distilled water and anisodine in turn as a negative control; and Group P with oral administration of piracetam as a positive control. After adaption for 1 week in lab room, sample and medicine were orally administrated for 4 weeks as follows: Group $\mathrm{H}_{1}$ and Group $\mathrm{HA}_{1}$ with a dose of $333.3 \mathrm{mg} / \mathrm{kg} \mathrm{SPH}$, Group $\mathrm{H}_{2}$ and Group $\mathrm{HA}_{2}$ with a dose of $333.3 \mathrm{mg} / \mathrm{kg} \mathrm{WPH}$, Group $\mathrm{H}_{3}$ and Group $\mathrm{HA}_{3}$ with a dose of $333.3 \mathrm{mg} / \mathrm{kg}$ WPH, Group C and Group CA with equivalent distilled water, and Group P with a dose of $800 \mathrm{mg} / \mathrm{kg}$ piracetam. The doses of SPH, WPH, $\mathrm{PPH}$ and piracetam were 10 times that of human adult with $60 \mathrm{~kg}$ body weight. Then, all groups were trained and tested in a platform recorder (BW-YLS-3TB, Shanghai Biowill Co. Ltd.). During the experiments, sample and medicine were continuously and individually administrated as usual. But a dose of $10 \mathrm{mg} / \mathrm{kg}$ anisodine was administrated to Group $\mathrm{HA}_{1}$, Group $\mathrm{HA}_{2}$, Group $\mathrm{HA}_{3}$, and Group CA after $1 \mathrm{~h}$ of the last administration at the 4 th week treatment.

The training and testing experiments were performed at the second day of the last administration for Groups $\mathrm{C}, \mathrm{H}_{1}$, $\mathrm{H}_{2}$, and $\mathrm{H}_{3}$; at 10 min later of last administrating anisodine for Groups $\mathrm{HA}_{1}, \mathrm{HA}_{2}, \mathrm{HA}_{3}$, and CA. At the beginning of experiments, all mice were placed in the platform recorder. After adaption for $3 \mathrm{~min}, 36 \mathrm{~V}$ alternating current was used to stimulate them. Given one time of training, the learned score (obtained memory, OM) was then recorded as the latent period of first jumping to platform [11] and times of wrong jumping in $5 \mathrm{~min}$ (WT). After $24 \mathrm{~h}$, mice were retested to record the latent time of first jumping to platform, times of wrong jumping in $3 \mathrm{~min}$, and quantity of animals shocked by electric (ESA). Consolidated memory (CM) was calculated as the percentage of wrong reactive animals (WRA, (1)). After 5 days later, memory recessive experiment was performed with the procedure of retesting and recorded as recurred memory (RM):

$$
\text { WRA } \%=\frac{\text { the quantity of ESA }}{\text { total animals in one group }} \times 100 \% .
$$

All experimental protocols were approved by the local Ethical Committee, and all experiments were performed in accordance with the NIH Guide for Care and Use of Laboratory Animals (1985).

2.9. Statistical Analysis. Statistical analysis was performed using the statistical package SPSS 17.0 (SPSS Inc., Chicago, IL) with one-way ANOVA. Duncan's multiple range test and
TABle 1: Amino acid composition (g/kg) in SPH, WPH, and $\mathrm{PPH}^{*}$.

\begin{tabular}{lccc}
\hline & SPH & WPH & PPH \\
\hline Asp & $111.1 \pm 3.7^{\mathrm{a}}$ & $103.0 \pm 5.2^{\mathrm{a}, \mathrm{b}}$ & $97.2 \pm 7.5^{\mathrm{b}}$ \\
Thr & $45.5 \pm 0.9^{\mathrm{a}}$ & $38.3 \pm 1.0^{\mathrm{b}}$ & $34.2 \pm 2.5^{\mathrm{c}}$ \\
Ser & $67.1 \pm 1.8^{\mathrm{a}}$ & $43.7 \pm 1.4^{\mathrm{b}}$ & $44.3 \pm 1.9^{\mathrm{b}}$ \\
Glu & $189.3 \pm 3.5^{\mathrm{b}}$ & $196.7 \pm 8.5^{\mathrm{b}}$ & $227.8 \pm 6.4^{\mathrm{a}}$ \\
Gly & $61.3 \pm 0.9^{\mathrm{a}}$ & $43.4 \pm 1.9^{\mathrm{b}}$ & $64.5 \pm 2.6^{\mathrm{a}}$ \\
Ala & $71.2 \pm 1.1^{\mathrm{b}}$ & $82.9 \pm 4.1^{\mathrm{a}}$ & $40.4 \pm 5.1^{\mathrm{c}}$ \\
$(\text { Cys })_{2}$ & $5.3 \pm 0.2^{\mathrm{a}}$ & $2.1 \pm 0.4^{\mathrm{b}}$ & $5.0 \pm 0.6^{\mathrm{a}}$ \\
Val & $56.3 \pm 2.3^{\mathrm{a}}$ & $52.6 \pm 2.6^{\mathrm{a}, \mathrm{b}}$ & $46.5 \pm 4.4^{\mathrm{b}}$ \\
Met & $16.3 \pm 0.5^{\mathrm{b}}$ & $31.9 \pm 3.1^{\mathrm{a}}$ & $17.5 \pm 2.0^{\mathrm{b}}$ \\
Ile & $46.4 \pm 1.8^{\mathrm{a}}$ & $36.6 \pm 1.7^{\mathrm{b}}$ & $40.8 \pm 3.9^{\mathrm{b}}$ \\
Leu & $76.1 \pm 2.8^{\mathrm{a}}$ & $65.9 \pm 2.4^{\mathrm{b}}$ & $65.1 \pm 3.2^{\mathrm{b}}$ \\
Tyr & $27.3 \pm 2.0^{\mathrm{c}}$ & $45.4 \pm 1.2^{\mathrm{a}}$ & $41.2 \pm 1.2^{\mathrm{b}}$ \\
Phe & $36.8 \pm 0.8^{\mathrm{c}}$ & $46.5 \pm 1.4^{\mathrm{a}}$ & $43.9 \pm 1.8^{\mathrm{b}}$ \\
His & $27.1 \pm 0.7^{\mathrm{b}}$ & $22.4 \pm 2.5^{\mathrm{c}}$ & $44.5 \pm 2.0^{\mathrm{a}}$ \\
Lys & $57.6 \pm 2.4^{\mathrm{a}}$ & $24.9 \pm 1.4^{\mathrm{c}}$ & $37.0 \pm 1.5^{\mathrm{b}}$ \\
Arg & $66.0 \pm 1.6^{\mathrm{c}}$ & $128.3 \pm 6.5^{\mathrm{a}}$ & $107.3 \pm 6.8^{\mathrm{b}}$ \\
Pro & $39.4 \pm 0.9^{\mathrm{b}}$ & $35.4 \pm 1.3^{\mathrm{c}}$ & $42.8 \pm 2.0^{\mathrm{a}}$ \\
\hline
\end{tabular}

${ }^{*}$ The values in the same row followed by different letters are significantly different $(p<0.05)$.

the independent-sample $t$-test were employed for comparing mean values and evaluating significant differences (at $p<$ $0.05,0.01$, and 0.001) among treatments. When necessary, data are expressed as mean $\pm \mathrm{SD}$, and variance analysis was carried out using Origin 7.5.

\section{Results and Discussion}

3.1. Amino Acids Composition Analysis. The amino acid composition of proteins and peptides is widely recognized as an important index of their function and bioactivity [12]. The amino acid composition of SPH, WPH, and PPH is shown in Table 1. Obviously higher contents of Glu (189.2-227.8 g/kg) and Asp (97.2-111.1 g/kg) were observed in all the protein hydrolysates, due to their plant-derived protein sources. The highest $(p<0.05)$ content of Asp, Thr, Ser, Gly, Ile, Leu, and Lys was observed in SPH, while WPH had the most Ala, Met, Phe, and Arg and PPH had higher contents of Glu, His, and Pro.

Some amino acids have been reported to have effect on cognitive performance. In vitro, amino acids show some influences on neurite outgrowth and synaptic plasticity. Ser was recently shown to promote process outgrowth and differentiation of chick retinal explants [13]. SPH exhibited the highest content of Ser; this might be useful for its neurotrophic function. Arginine, as a biosynthesis precursor, would be transformed to nitric oxides (NO) in a NADPHdependent reaction, which could modulate learning and memory in cognitive performance [14]. And Paul et al. [15] found that the administration of Arg exhibited strong inhibitory activity against picrotoxin impairing on both learning and memory processes. The order of Arg content was $\mathrm{WPH}>\mathrm{PPH}>\mathrm{SPH}$. Therefore, the effects of different 


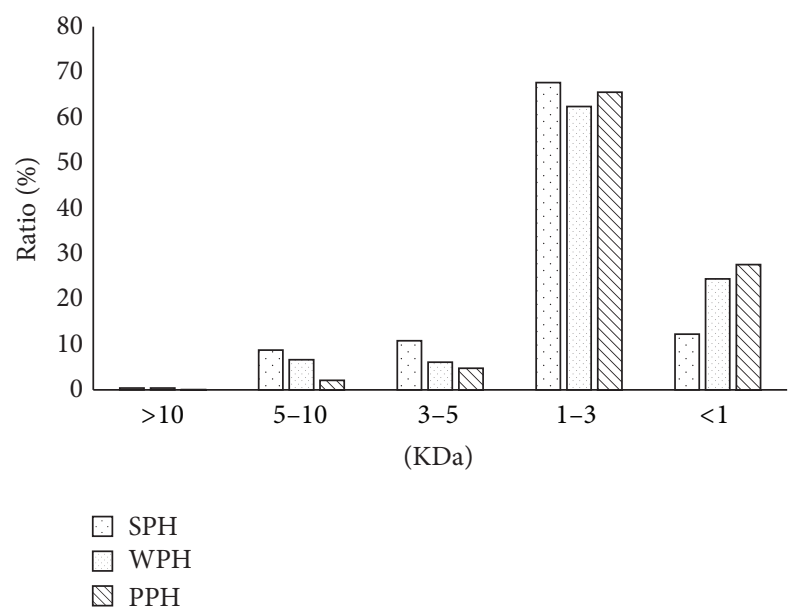

FIGURE 1: The molecular weight distribution of peptides from SPH, $\mathrm{WPH}$, and $\mathrm{PPH}$.

protein hydrolysates on memory improving might be variety with the content of Arg. Tyrosine/phenylalanine depletion lowers dopamine synthesis which involves reinforcement, motor control, and frontal lobe functions and impairs working memory performance [16]. The highest content of Tyr and Phe was observed in WPH. This might be good for its function on working memory. The contents of above amino acids were relatively high in the three protein hydrolysates, and they would be potentially effective on cognitive performance. However, another study showed that cerebrolysin (peptide/amino acids mixtures) could protect the cell against degeneration and apoptotic effects, while amino acids mixture (the same amino acid ratio of the free amino acids naturally found in cerebrolysin) could not show the corresponding effect [13]. In the results, the relationship between amino acids and efficacy was not clearly direct relationship, suggesting that the function of active peptide may be related to the specific peptide segment.

3.2. Molecular Weight Distribution of Hydrolysates. As shown in Figure 1, all the hydrolysates (SPH, WPH, and PPH) were rich in fractions with molecular weight $<10 \mathrm{KDa}$ and were dominated by the fractions with $1-3 \mathrm{KDa}$. It indicated that the proteins were greatly degraded by papain. It was notable that ratios for 5-10 KDa, 3-5 KDa, and 1-3 KDa fractions were relatively higher $(8.77 \%, 10.82 \%$, and $67.70 \%$, resp.), and only $12.30 \%$ of $<1 \mathrm{KDa}$ was observed in SPH. Moreover, for WPH, much more large peptides were degraded into small peptides; the percentages for all the three fractions were smaller than that for $\mathrm{SPH}$, whereas $\mathrm{PPH}$ was mainly composed of $1-3 \mathrm{KDa}$ and $<1 \mathrm{KDa}$ fractions $(65.54 \%$ and $27.6 \%)$. Results revealed that the peanut proteins were greatest hydrolyzed into small peptides by papain, followed by walnut protein and soybean protein.

Proteins were degraded into peptides with various bioactivity, and it is reported that small peptides showed stronger antioxidant activity, especially the peptides with $1-3 \mathrm{KDa}$ [17]. As the results show, it was suggested that the three protein hydrolysates showed strong bioactivity and potential cytoprotective benefits. However, there was little literature on the relationship between peptide molecular weight and the function of improving memory. Arginine vasopressin (AVP), as a octapeptide, showed lower behavioral activity than its hexapeptide ([4-9] AVP) and tetrapeptide ([5-8] AVP) fragments in a radial maze test [18], while both [6-8] AVP and [5-7] AVP demonstrated no activity in the same test. It indicated that the function of active peptide may be related to the specific peptide segment, not direct relationship to molecular weight [19].

3.3. Characterization of the PC12 Cell Model. The models of $\mathrm{H}_{2} \mathrm{O}_{2}$ damaged $\mathrm{PC} 12$ cells and anisodine-treated mice were utilized in some studies [20-24].

As shown in Figure 2(a), initially, PC12 cells grew along the plate wall showing ovoid or polygon shaped with discernible cell boundaries. And no cytoplasmic extensions or neurites are present. Exposure to $50 \mathrm{ng} / \mathrm{mL}$ NGF and PC12 line began to extend neurite after $24 \mathrm{~h}$ and, by $4-10$ days, displayed dense neurite networks (Figure 2(b)).

Microtubule-associated protein 2 (MAP2) is a common nerve cells marker, due to be abundance in dendrites in vivo in almost all neurites. Figure 2(c) showed that no brown (pictures were not showing the color) was observed in cytoplasm of PC12 cells. Interestingly, after 7 days of exposure to NGF, cytoplasm and neurite all showed obviously brown (Figure 2(d)). It revealed that the NGF-treated PC12 cells had the characteristic of secreting nerve cells.

In order to analyze the protective effects of the protein hydrolysates ( $\mathrm{SPH}, \mathrm{WPH}$, and $\mathrm{PPH})$, oxidative stress was induced in PC12 cells by hydrogen peroxide $\left(\mathrm{H}_{2} \mathrm{O}_{2}\right)$. A clear dose dependency of viability after $\mathrm{H}_{2} \mathrm{O}_{2}(0.005 \mathrm{mM}-$ $4.0 \mathrm{mM}$ ) treatment was exhibited by MTT method. And $\mathrm{H}_{2} \mathrm{O}_{2}$ at concentration of $0.1 \mathrm{mM}$ was used for further experiments because of the resulted viability of $61.76 \%$ (data not shown). As shown in Figure 3, in low concentration $(0.10-0.20 \mathrm{mg} / \mathrm{mL})$, only SPH exhibited significantly $(p<$ 0.05 ) inhibitory activity against $\mathrm{H}_{2} \mathrm{O}_{2}$-induced toxicity, while significantly $(p<0.01)$ inhibitory activities were observed in SPH and PPH with $5.00 \mathrm{mg} / \mathrm{mL}$ and $1.00 \mathrm{mg} / \mathrm{mL}$, suggesting that they could exhibit various neurotrophic effects results in no significantly harm to PC12 cells.

3.4. Flow Cytometry Results of SPH, WPH, and PPH Pretreatment in $\mathrm{H}_{2} \mathrm{O}_{2}$-Induced PC12 Cell Apoptosis. Flow cytometry was applied to study the neuroprotective capacity in cultured PC12 cells of SPH, WPH, and PPH. According to Table 2, when the PC12 cells were treated with $0.1 \mathrm{mM} \mathrm{H}_{2} \mathrm{O}_{2}$, nonviable apoptotic cells and viable apoptotic cells significantly $(p<0.05)$ increased to $24.63 \%$ and $63.31 \%$, respectively, while viable cells significantly $(p<0.05)$ decreased to $11.62 \%$. No effects on viability were found by SPH treatment at $1 \mathrm{mg} / \mathrm{mL}$, whereas viable cells significantly $(p<0.01)$ increased to $22.07 \%$, and nonviable apoptotic cells significantly $(p<$ 0.01 ) decreased to $15.60 \%$ in the presence of $2 \mathrm{mg} / \mathrm{mL} \mathrm{SPH}$. It is notable that inverse results were obtained with the concentration increasing to $5.00 \mathrm{mg} / \mathrm{mL}$, viable apoptotic cells displayed drastic decrease to $7.94 \%(p<0.01)$, and 


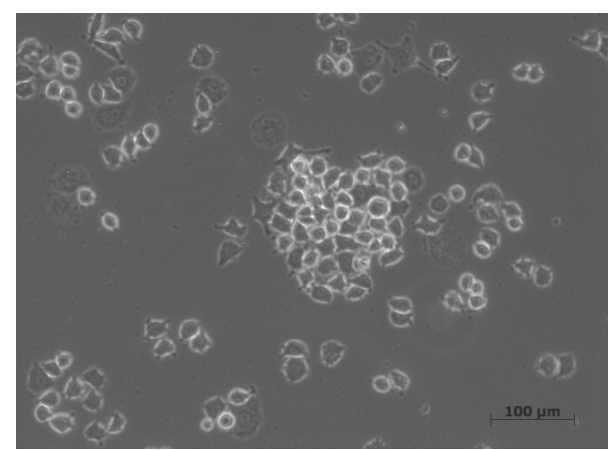

(a)

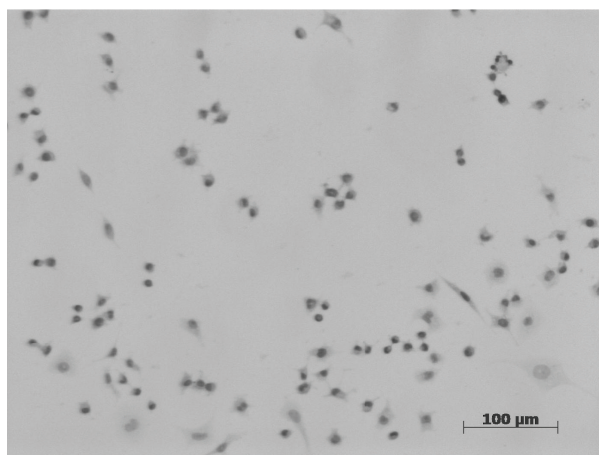

(c)

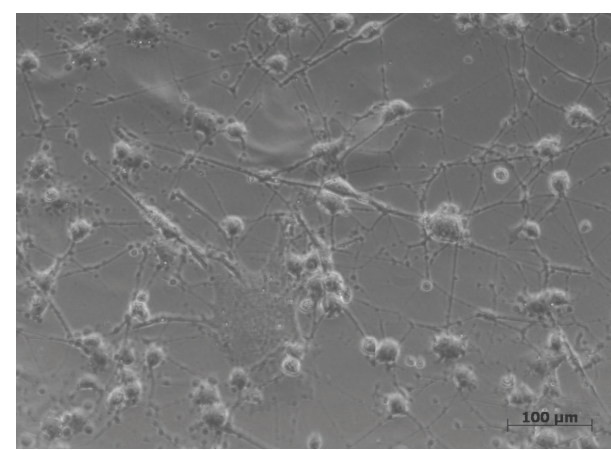

(b)

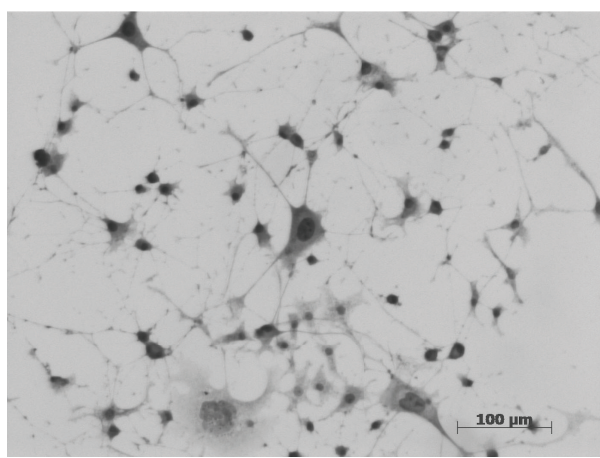

(d)

FIGURE 2: The characterization of the PC12 cell model. (a)/(b) The morphologies of PC12 cells before/after exposure to NGF. (c)/(d) The staining results of microtubule-associated protein 2 (MAP2) before/after exposure to NGF. (Scale bar $=100 \mu \mathrm{m}$.)

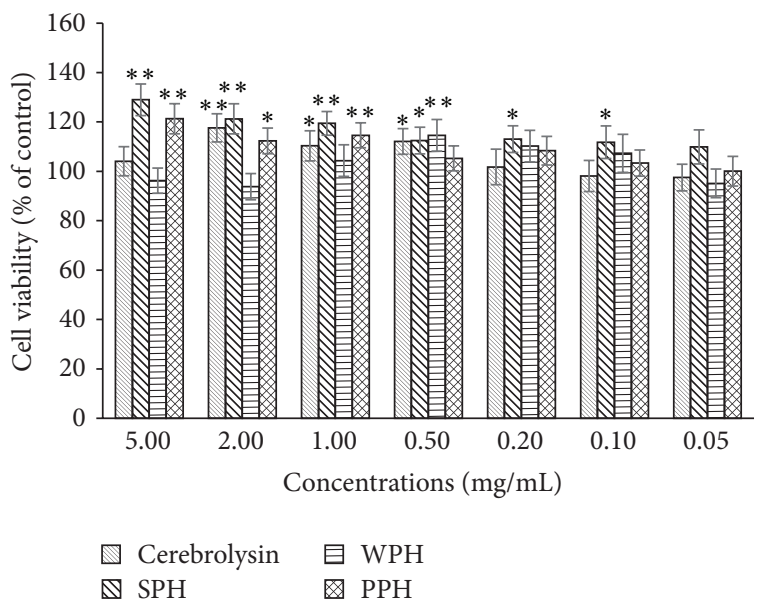

Figure 3: Promoting effect of different hydrolysates in cultured PC12 cells. Each value indicates a mean $\pm \mathrm{SD}(n=3) .{ }^{*} p<0.05$ and ${ }^{* *} p<0.01$, compared with control group.

nonviable apoptotic cells significantly $(p<0.01)$ increased to $75.69 \%$.

Similar dose-response characteristics for $\mathrm{WPH}$ and $\mathrm{PPH}$ first showed effects in all cells at $1 \mathrm{mg} / \mathrm{mL}$, whereas higher concentration $(2 \mathrm{mg} / \mathrm{mL})$ resulted in an increase in viable cells and a decline in nonviable apoptotic cells. Conversely, viable apoptotic cells decreased and nonviable apoptotic cells increased, when the concentration increased to $5 \mathrm{mg} / \mathrm{mL}$.

It was discovered that $\mathrm{SPH}$ showed the highest activity of enhancing normal PC12 cells viability (Figure 3) followed by $\mathrm{PPH}, \mathrm{WPH}$, and cerebrolysin. And all hydrolysates could significantly $(p<0.05)$ decrease the rate of mechanical damage in PC12 cells.

\subsection{Effects of SPH, WPH, and PPH on Animal's Cognition} Trials. To study the effects of various protein hydrolysates on memory-impairment in vivo, animal cognition trials were conducted. As shown in Table 3(a), during the acquisition session, the control group showed $73.3 \%$ error response rate. After oral administration of samples in four weeks, the positive-, $\mathrm{SPH}-$, and WPH-treated groups exhibited significantly $(p<0.05)$ decreased wrong time and error response rate and increased latent period, compared to control group. However, in the consolidation model, piracetam and protein hydrolysates except for SPH would significantly $(p<0.05)$ decreased wrong time and error response rate, whereas they did not affect latent period.

In order to investigate whether the protein hydrolysates could improve impaired memory, anisodine treatment mice model was applied. Anisodine, as a new ganglion blocking agent, could result in acetylcholine decrease and memory deficits in the mouse brain [25]. Piracetam that has positive effects on the cognitive performance of Alzheimer's disease patients $[26,27]$ was taken as a positive control. It is notable 
TABLE 2: Flow cytometry analysis for the neuroprotective effects of SPH, WPH, and $\mathrm{PPH}$ on $\mathrm{H}_{2} \mathrm{O}_{2}$-induced apoptosis in cultured PC12 cells.

\begin{tabular}{|c|c|c|c|c|c|}
\hline Sample & $\begin{array}{l}\text { Added amount } \\
\quad(\mathrm{mg} / \mathrm{mL})\end{array}$ & $\begin{array}{c}\text { Mechanically } \\
\text { damaged cells } \\
(\%)\end{array}$ & $\begin{array}{c}\text { Nonviable } \\
\text { apoptotic cells } \\
(\%)\end{array}$ & Viable cells (\%) & $\begin{array}{l}\text { Viable apoptotic } \\
\text { cells }(\%)\end{array}$ \\
\hline Control & - & $7.75 \pm 0.68$ & $4.37 \pm 0.32$ & $65.91 \pm 4.79$ & $21.97 \pm 2.15$ \\
\hline $\mathrm{H}_{2} \mathrm{O}_{2}$ & - & $0.44 \pm 0.12$ & $24.63 \pm 3.25$ & $11.62 \pm 2.61$ & $63.31 \pm 7.05$ \\
\hline \multirow{3}{*}{$\mathrm{H}_{2} \mathrm{O}_{2}+$ cerebrolysin } & 1 & $0.32 \pm 0.11$ & $23.29 \pm 4.18$ & $12.08 \pm 1.49$ & $64.31 \pm 6.74$ \\
\hline & 2 & $0.32 \pm 0.19$ & $17.59 \pm 1.02^{*}$ & $18.08 \pm 1.83$ & $64.01 \pm 10.08$ \\
\hline & 5 & $6.49 \pm 0.76$ & $70.08 \pm 8.70^{* *}$ & $12.54 \pm 2.04$ & $10.89 \pm 1.73^{* *}$ \\
\hline \multirow{3}{*}{$\mathrm{H}_{2} \mathrm{O}_{2}+\mathrm{SPH}$} & 1 & $0.14 \pm 0.05$ & $25.74 \pm 2.56$ & $11.69 \pm 1.87$ & $63.43 \pm 6.24$ \\
\hline & 2 & $0.12 \pm 0.04$ & $15.60 \pm 3.01^{*}$ & $22.07 \pm 3.47^{*}$ & $62.21 \pm 7.22$ \\
\hline & 5 & $3.46 \pm 0.95^{*}$ & $75.69 \pm 9.36^{* *}$ & $12.91 \pm 2.26$ & $7.94 \pm 1.88^{* *}$ \\
\hline \multirow{3}{*}{$\mathrm{H}_{2} \mathrm{O}_{2}+\mathrm{WPH}$} & 1 & $0.18 \pm 0.06^{*}$ & $25.25 \pm 5.06$ & $12.32 \pm 1.69$ & $62.25 \pm 6.54$ \\
\hline & 2 & $0.25 \pm 0.07^{*}$ & $16.14 \pm 1.89^{*}$ & $19.02 \pm 2.03^{*}$ & $64.59 \pm 6.01$ \\
\hline & 5 & $5.87 \pm 0.84^{* *}$ & $76.57 \pm 6.98^{* *}$ & $11.57 \pm 1.21$ & $5.99 \pm 0.79^{* *}$ \\
\hline \multirow{3}{*}{$\mathrm{H}_{2} \mathrm{O}_{2}+\mathrm{PPH}$} & 1 & $1.09 \pm 0.42$ & $22.87 \pm 3.13$ & $12.91 \pm 2.07$ & $63.13 \pm 6.43$ \\
\hline & 2 & $0.16 \pm 0.04^{*}$ & $14.25 \pm 2.78^{*}$ & $15.14 \pm 2.69$ & $70.18 \pm 7.22$ \\
\hline & 5 & $0.70 \pm 0.10$ & $62.66 \pm 6.42^{* *}$ & $15.04 \pm 3.02$ & $21.60 \pm 4.56$ \\
\hline
\end{tabular}

Each value indicates mean $\pm \mathrm{SD}(n=3) .{ }^{*} p<0.01$ and ${ }^{* *} p<0.001$, compared with the $\mathrm{H}_{2} \mathrm{O}_{2}$-treated group.

TABLE 3: Effects of SPH, WPH, and PPH on memory acquisition, consolidation, and retrieval in normal mice in step-down test in normal and anisodine-treated mice.

(a)

\begin{tabular}{|c|c|c|c|c|c|c|c|c|c|}
\hline \multirow[b]{2}{*}{ Sample } & \multicolumn{3}{|c|}{$\mathrm{OM}$} & \multicolumn{3}{|c|}{$\mathrm{CM}$} & \multicolumn{3}{|c|}{$\mathrm{RM}$} \\
\hline & $\begin{array}{l}\text { WT in } \\
5 \mathrm{~min}\end{array}$ & $\begin{array}{c}\mathrm{LP} \\
(\mathrm{min})\end{array}$ & $\begin{array}{c}\text { Percentage } \\
\text { of WRA } \\
(\%)\end{array}$ & $\mathrm{WT}$ in $3 \mathrm{~min}$ & $\begin{array}{c}\mathrm{LP} \\
(\mathrm{min})\end{array}$ & $\begin{array}{c}\text { Percentage } \\
\text { of WRA } \\
(\%)\end{array}$ & $\begin{array}{l}\text { WT in } \\
3 \mathrm{~min}\end{array}$ & $\begin{array}{c}\mathrm{LP} \\
(\mathrm{min})\end{array}$ & $\begin{array}{c}\text { Percentage of } \\
\text { WRA (\%) }\end{array}$ \\
\hline Control & $1.1 \pm 1.1$ & $2.10 \pm 1.25$ & 73.3 & $0.8 \pm 1.1$ & $2.11 \pm 1.05$ & 46.7 & $1.1 \pm 1.1$ & $1.63 \pm 1.31$ & 60.0 \\
\hline Piracetam & $1.0 \pm 1.1^{*}$ & $3.20 \pm 1.81^{*}$ & $53.3^{*}$ & $0.5 \pm 0.7$ & $2.33 \pm 0.86$ & 40.0 & $0.2 \pm 0.4^{*}$ & $2.85 \pm 0.33^{* *}$ & $20.0^{* *}$ \\
\hline SPH & $0.8 \pm 1.0^{*}$ & $3.08 \pm 2.13^{*}$ & $46.7^{*}$ & $0.8 \pm 0.9$ & $2.01 \pm 1.04$ & 53.3 & $0.3 \pm 0.8^{*}$ & $2.76 \pm 0.66^{* *}$ & $20.0^{* *}$ \\
\hline WPH & $0.5 \pm 0.6^{* *}$ & $3.15 \pm 2.07^{*}$ & $46.7^{*}$ & $0.5 \pm 0.7^{*}$ & $2.30 \pm 1.03$ & $33.3^{*}$ & $0.1 \pm 0.4^{* *}$ & $2.72 \pm 0.78^{* *}$ & $13.3^{* *}$ \\
\hline $\mathrm{PPH}$ & $1.3 \pm 1.0$ & $2.20 \pm 1.51$ & 73.3 & $0.4 \pm 0.6^{*}$ & $2.38 \pm 0.91$ & $33.3^{*}$ & $0.2 \pm 0.4^{* *}$ & $2.85 \pm 0.33^{* *}$ & $20.0^{* *}$ \\
\hline
\end{tabular}

(b)

\begin{tabular}{|c|c|c|c|c|c|c|c|c|c|}
\hline \multirow[b]{2}{*}{ Sample } & \multicolumn{3}{|c|}{$\mathrm{OM}$} & \multicolumn{3}{|c|}{$\mathrm{CM}$} & \multicolumn{3}{|c|}{$\mathrm{RM}$} \\
\hline & $\begin{array}{l}\text { WT in } \\
5 \mathrm{~min}\end{array}$ & $\mathrm{LP}(\min )$ & $\begin{array}{c}\text { Percentage } \\
\text { of WRA } \\
(\%)\end{array}$ & $\mathrm{WT}$ in $3 \mathrm{~min}$ & $\mathrm{LP}(\min )$ & $\begin{array}{c}\text { Percentage } \\
\text { of WRA } \\
(\%)\end{array}$ & $\mathrm{WT}$ in $3 \mathrm{~min}$ & $\mathrm{LP}(\min )$ & $\begin{array}{c}\text { Percentage } \\
\text { of WRA } \\
(\%)\end{array}$ \\
\hline Control & $3.4 \pm 2.8$ & $2.22 \pm 1.52$ & 80.0 & $1.2 \pm 1.1$ & $1.79 \pm 1.22$ & 60.0 & $0.9 \pm 1.7$ & $2.38 \pm 0.94$ & 33.3 \\
\hline Piracetam & $2.8 \pm 3.5$ & $2.34 \pm 1.94$ & 80.0 & $0.6 \pm 1.1^{*}$ & $3.83 \pm 1.83^{* *}$ & $33.3^{*}$ & $0.3 \pm 0.6^{* *}$ & $4.22 \pm 1.36^{* *}$ & $26.7^{*}$ \\
\hline SPH & $1.9 \pm 2.6^{*}$ & $2.32 \pm 2.08$ & $60.0^{*}$ & $0.3 \pm 0.6^{* *}$ & $2.74 \pm 0.72^{*}$ & $20.0^{* *}$ & $0.5 \pm 0.7^{*}$ & $2.69 \pm 0.73^{*}$ & 33.3 \\
\hline WPH & $3.7 \pm 3.6$ & $1.51 \pm 1.74^{*}$ & $56.7^{*}$ & $0.5 \pm 1.1^{* *}$ & $2.73 \pm 0.59^{*}$ & $20.0^{* *}$ & $0.8 \pm 1.1$ & $2.45 \pm 0.80$ & 53.3 \\
\hline $\mathrm{PPH}$ & $3.5 \pm 2.8$ & $1.32 \pm 1.54^{*}$ & $53.3^{*}$ & $0.5 \pm 0.6^{* *}$ & $2.65 \pm 0.48^{*}$ & $40.0^{*}$ & $0.3 \pm 0.7^{* *}$ & $2.81 \pm 0.55^{*}$ & $20.0^{*}$ \\
\hline
\end{tabular}

Note: step-down test results (a) in normal mice trial and (b) in anisodine-treated mice trials. OM, obtained memory group; CM, consolidated memory group; RM, recurred memory group; WT, wrong times of jumping out of the platform; ESA, electric shocked animals; WRA, wrong reactive animals; LP, the latent period of first jumping. Each value indicates mean $\pm \mathrm{SD}(n=3) .{ }^{*} p<0.05$ and ${ }^{* *} p<0.01$, compared with control ( $t$-test). 
that anisodine could significantly $(p<0.05)$ deteriorate learning and memory ability of mice (Table $3(\mathrm{~b})$ ) resulting in much more wrong time and error response rate and less latent period. Pretreatment with piracetam and SPH would decrease the wrong time and error response rate and increase latent period of anisodine-treated mice compared to control group. In the consolidation session, piracetam and three protein hydrolysates could improve memory ability of memory-impairment mice. However, except for $\mathrm{WPH}$, the other two protein hydrolysates could also significantly $(p<$ 0.05 ) affect the retrieval memory.

\section{Conclusion}

The neuroprotective activity has been discovered in some hydrolysates from animal and plant proteins. Cerebrolysin is the famous one which might offer small improvements to symptoms of Alzheimer's disease and vascular dementia [28]. And similar activity was observed in other protein hydrolysates, such as glutathione [29], wheat germ protein hydrolysate [20], and hempseed protein hydrolysate [21]. Jiang et al. [30] also reported that the papain hydrolysate from walnut protein contained peptides with high ACE inhibitory activity. Thus, it is possible that the hydrolysates from soybean protein, walnut protein, and peanut have the neuroprotective activity. In the present study, all the three hydrolysates ( $\mathrm{SPH}, \mathrm{WPH}$, and $\mathrm{PPH}$ ) showed large amount of neurotrophic amino acids and were dominated by peptides with 1-3 KDa. The three hydrolysates could reduce the rate of nonviable apoptotic cells at the concentration of $2 \mathrm{mg} / \mathrm{mL}$. And $\mathrm{SPH}$ showed higher activity against $\mathrm{H}_{2} \mathrm{O}_{2}-$ induced toxicity than the other hydrolysates (WPH, PPH) and cerebrolysin. In addition, the results from animal's cognition test indicated that three hydrolysates could present partly better effect of improving recurred memory ability of normal mice and consolidated memory ability of anisodinetreated mice. Therefore, soybean, walnut, and peanut protein hydrolysates were proved to be potential food raw materials for ameliorating neurodegenerative disorders. However, the key peptides contributing to special function characteristics of them are still not clear. Further work on purification and identification of soy and walnut protein peptides is worthy to be carried out.

\section{Competing Interests}

The authors declare that there are no competing interests regarding the publication of this paper.

\section{Acknowledgments}

The program was supported by the Strategic Emerging Industry Key Scientific and Technological Program of Guangdong Province (no. 2012A020800002 and no. 2012A080800014) from the School of Food Science and Engineering, South China University of Technology.

\section{References}

[1] J. C. Cruz and L.-H. Tsai, "Cdk5 deregulation in the pathogenesis of Alzheimer's disease," Trends in Molecular Medicine, vol. 10, no. 9, pp. 452-458, 2004.

[2] J. Liu, Z. Chen, J. He, Y. Zhang, T. Zhang, and Y. Jiang, "Anti-oxidative and anti-apoptosis effects of egg white peptide, Trp-Asn-Trp-Ala-Asp, against $\mathrm{H}_{2} \mathrm{O}_{2}$-induced oxidative stress in human embryonic kidney 293 cells," Food \& Function, vol. 5, no. 12, pp. 3179-3188, 2014.

[3] B. T. Casali, A. W. Corona, M. M. Mariani, J. C. Karlo, K. Ghosal, and G. E. Landreth, "Omega-3 fatty acids augment the actions of nuclear receptor agonists in a mouse model of Alzheimer's disease," The Journal of Neuroscience, vol. 35, no. 24, pp. 91739181, 2015.

[4] M. M. Corrada, C. H. Kawas, J. Hallfrisch, D. Muller, and R. Brookmeyer, "Reduced risk of Alzheimer's disease with high folate intake: the Baltimore Longitudinal Study of Aging," Alzheimer's \& Dementia, vol. 1, no. 1, pp. 11-18, 2005.

[5] B. Muthaiyah, M. M. Essa, V. Chauhan, and A. Chauhan, "Protective effects of walnut extract against amyloid beta peptide-induced cell death and oxidative stress in PC12 cells," Neurochemical Research, vol. 36, no. 11, pp. 2096-2103, 2011.

[6] N. Chen, H. Yang, Y. Sun, J. Niu, and S. Liu, "Purification and identification of antioxidant peptides from walnut (Juglans regia L.) protein hydrolysates," Peptides, vol. 38, no. 2, pp. 344-349, 2012.

[7] S. N. Jamdar, V. Rajalakshmi, M. D. Pednekar, F. Juan, V. Yardi, and A. Sharma, "Influence of degree of hydrolysis on functional properties, antioxidant activity and ACE inhibitory activity of peanut protein hydrolysate," Food Chemistry, vol. 121, no. 1, pp. 178-184, 2010.

[8] J. Liu, W. Liu, D. Liu, M. Xu, and Y. Zhang, "Neuroprotective effects of soybean oligopeptides (sops) against $\mathrm{H}_{2} \mathrm{O}_{2}$-induced oxidative stress in PC12 cells," International Proceedings of Chemical, Biological \& Environmenta, vol. 65, p. 46, 2014.

[9] I. V. Damulin, N. N. Koberskaya, and É. A. Mkhitaryan, "Effects of cerebrolysin on moderate cognitive impairments in cerebral vascular insufficiency (a clinical-electrophysiological study)," Neuroscience and Behavioral Physiology, vol. 38, no. 6, pp. 639645, 2008.

[10] M. Fujiwara, Y. Ishida, N. Nimura, A. Toyama, and T. Kinoshita, "Postcolumn fluorometric detection system for liquid chromatographic analysis of amino and imino acids using ophthalaldehyde/N-acetyl-l-cysteine reagent," Analytical Biochemistry, vol. 166, no. 1, pp. 72-78, 1987.

[11] J.-Y. Ko, J.-H. Lee, K. Samarakoon, J.-S. Kim, and Y.-J. Jeon, "Purification and determination of two novel antioxidant peptides from flounder fish (Paralichthys olivaceus) using digestive proteases," Food \& Chemical Toxicology, vol. 52, no. 2, pp. 113120,2013

[12] C. F. Ajibola, J. B. Fashakin, T. N. Fagbemi, and R. E. Aluko, "Effect of peptide size on antioxidant properties of African yam bean seed (Sphenostylis stenocarpa) protein hydrolysate fractions," International Journal of Molecular Sciences, vol. 12, no. 10, pp. 6685-6702, 2011.

[13] M. Hartbauer, B. Hutter-Paier, and M. Windisch, "Effects of cerebrolysin on the outgrowth and protection of processes of cultured brain neurons," Journal of Neural Transmission, vol. 108, no. 5, pp. 581-592, 2001.

[14] F. S. dos Santos, L. A. da Silva, J. A. Pochapski et al., "Effects of Larginine and creatine administration on spatial memory in rats 
subjected to a chronic variable stress model," Pharmaceutical Biology, vol. 52, no. 8, pp. 1033-1038, 2014.

[15] V. Paul, L. Reddy, and P. Ekambaram, "Prevention of picrotoxin convulsions-induced learning and memory impairment by nitric oxide increasing dose of L-arginine in rats," Pharmacology Biochemistry and Behavior, vol. 75, no. 2, pp. 329-334, 2003.

[16] A. M. Linssen, W. J. Riedel, and A. Sambeth, "Effects of tyrosine/phenylalanine depletion on electrophysiological correlates of memory in healthy volunteers," Journal of Psychopharmacology, vol. 25, no. 2, pp. 230-238, 2011.

[17] S.-Y. Kim, J.-Y. Je, and S.-K. Kim, "Purification and characterization of antioxidant peptide from hoki (Johnius belengerii) frame protein by gastrointestinal digestion," Journal of Nutritional Biochemistry, vol. 18, no. 1, pp. 31-38, 2007.

[18] S. Tanabe, Y. Shishido, Y. Nakayama et al., "Effects of argininevasopressin fragment 4-9 on rodent cholinergic systems," Pharmacology Biochemistry \& Behavior, vol. 63, no. 4, pp. 549-553, 1999.

[19] M. Fujiwara, Y. Ohgami, K. Inada, and K. Iwasaki, "Effect of active fragments of arginine-vasopressin on the disturbance of spatial cognition in rats," Behavioural Brain Research, vol. 83, no. 1-2, pp. 91-96, 1997.

[20] K.-X. Zhu, X. Guo, X.-N. Guo, W. Peng, and H.-M. Zhou, "Protective effects of wheat germ protein isolate hydrolysates (WGPIH) against hydrogen peroxide-induced oxidative stress in PC12 cells," Food Research International, vol. 53, no. 1, pp. 297303, 2013.

[21] R.-R. Lu, P. Qian, Z. Sun et al., "Hempseed protein derived antioxidative peptides: purification, identification and protection from hydrogen peroxide-induced apoptosis in PC12 cells," Food Chemistry, vol. 123, no. 4, pp. 1210-1218, 2010.

[22] M.-M. Jin, L. Zhang, H.-X. Yu, J. Meng, Z. Sun, and R.R. Lu, "Protective effect of whey protein hydrolysates on $\mathrm{H}_{2} \mathrm{O}_{2}$-induced PC12 cells oxidative stress via a mitochondriamediated pathway," Food Chemistry, vol. 141, no. 2, pp. 847-852, 2013.

[23] Q.-X. Zhang, Y.-F. Ling, Z. Sun et al., "Protective effect of whey protein hydrolysates against hydrogen peroxide-induced oxidative stress on PC12 cells," Biotechnology Letters, vol. 34, no. 11, pp. 2001-2006, 2012.

[24] D.-H. Xu, S.-L. Huang, and S.-B. Xu, "Starfish sterol protects anisodine treated mice from impairment of learning and memory," Chinese Journal of Pharmacology \& Toxicology, vol. 14, no. 2, pp. 121-124, 2000.

[25] W. Duan and J. Zhang, "Effects of (-), (+)clausenamide on anisodine-induced acetylcholine decrease and associated memory deficits in the mouse brain," Acta Pharmaceutica Sinica, vol. 33, no. 4, pp. 259-263, 1998.

[26] L. Amaducci, "Phosphatidylserine in the treatment of Alzheimer's disease: results of a multicenter study," Psychopharmacology Bulletin, vol. 24, no. 1, pp. 130-134, 1988.

[27] T. Crook, W. Petrie, C. Wells, and D. C. Massari, "Effects of phosphatidylserine in Alzheimer's disease," Psychopharmacology Bulletin, vol. 28, no. 1, pp. 61-66, 1992.

[28] C. Riley, B. Hutter-Paier, M. Windisch, E. Doppler, H. Moessler, and R. Wronski, "A peptide preparation protects cells in organotypic brain slices against cell death after glutamate intoxication," Journal of Neural Transmission, vol. 113, no. 1, pp. 103-110, 2006.

[29] L. Gu, M. Zhao, W. Li et al., "Chemical and cellular antioxidant activity of two novel peptides designed based on glutathione structure," Food and Chemical Toxicology, vol. 50, no. 11, pp. 4085-4091, 2012.

[30] L. Jiang, H. Xu, and Y. Li, "Enzymolysis for preparation of ACE inhibitory peptides from walnut protein and studies on its function," Journal of Chinese Institute of Food Science \& Technology, vol. 15, no. 2, pp. 79-85, 2015. 

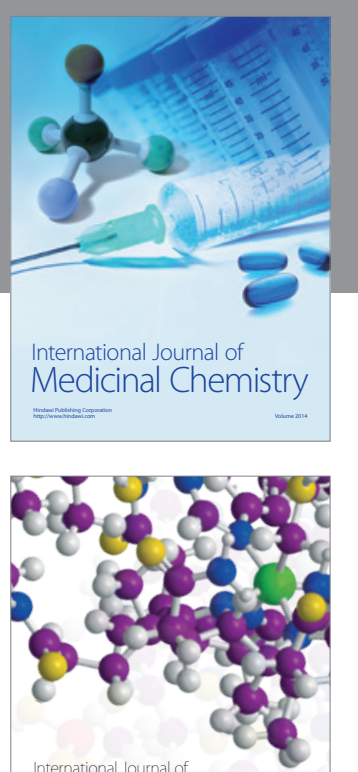

Carbohydrate Chemistry

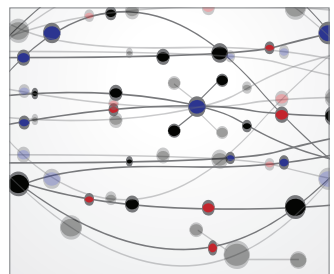

The Scientific World Journal
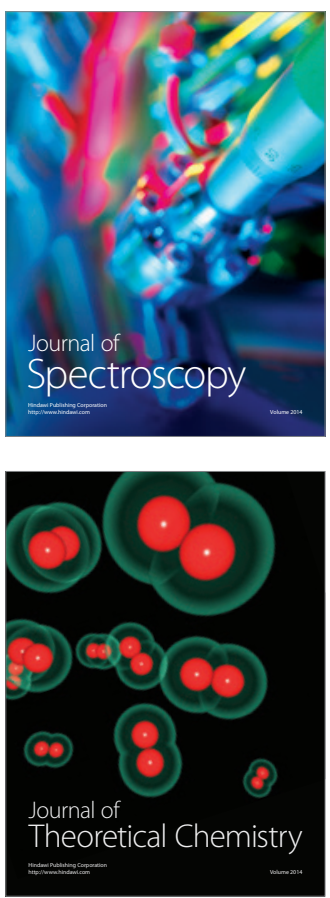
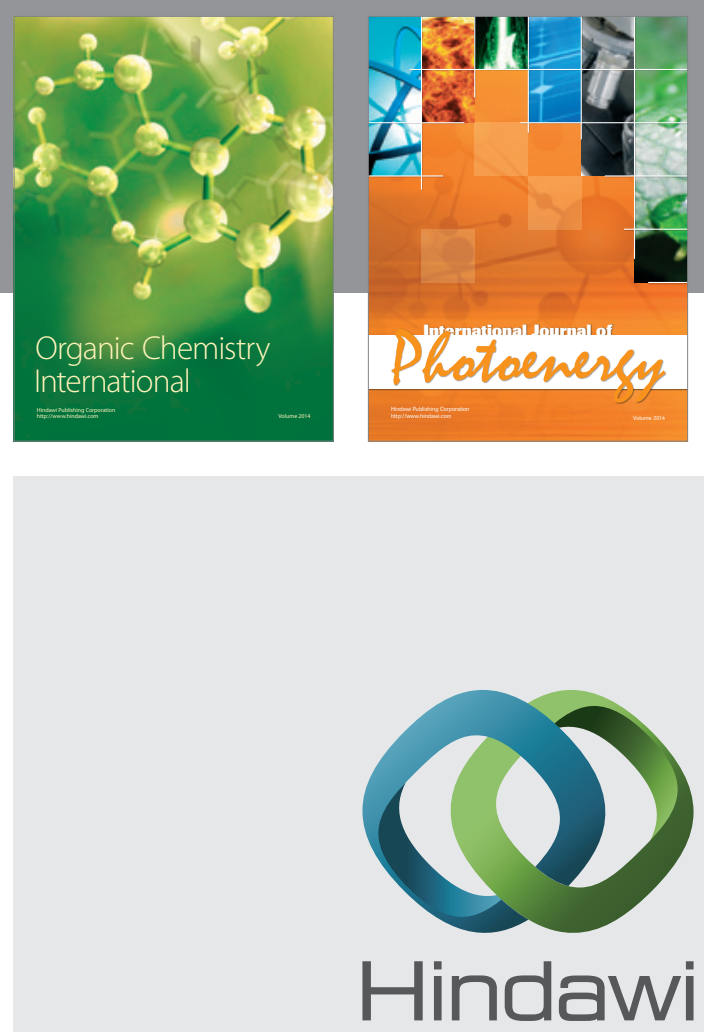

Submit your manuscripts at

http://www.hindawi.com

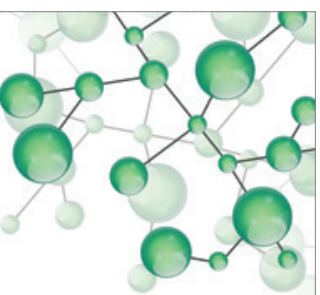

International Journal of

Inorganic Chemistry

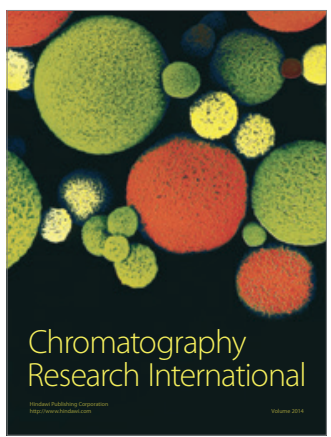

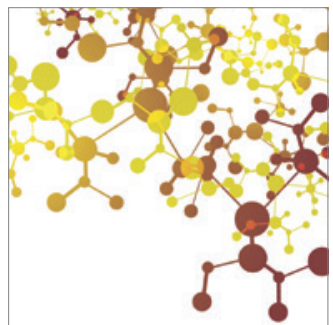

Applied Chemistry
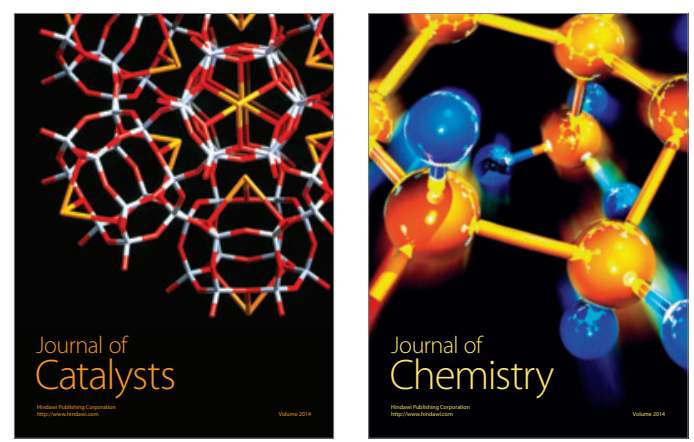
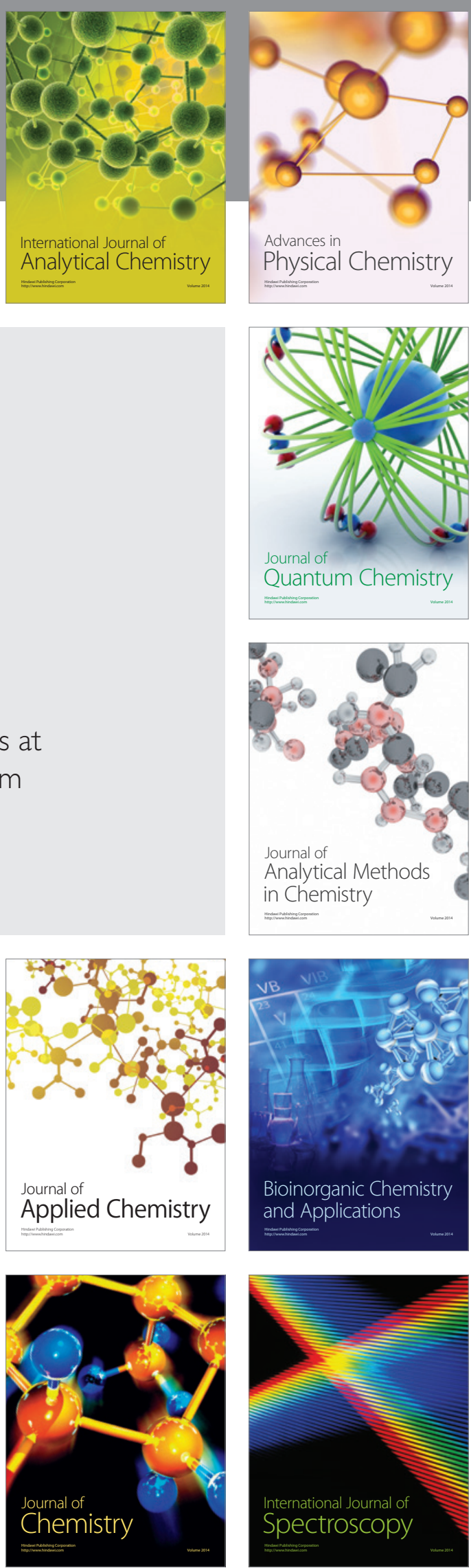